\title{
Refugee Mental Health: How Canada Supports the World's Most Vulnerable in Their Transition to Becoming Canadian
}

\author{
Ciarán Patrick Collins Galts, BSc ${ }^{1}$
}

${ }^{1}$ Faculty of Medicine, University of British Columbia

A B STRACT

Canada has been a sanctuary for refugees for many generations and is currently involved in welcoming a new cohort of Syrian refugees. Refugees represent a vulnerable population in Canada who require support in order to establish themselves and prevent the onset of mental illness. This article briefly describes Canada's experience with refugees and then explores issues faced by incoming Syrians focusing specifically on factors contributing to refugee mental health. It is evident that refugees face incredible difficulties on their journey but that the various support systems in Canada significantly bolster their resilience to mental health issues.

RÉ S U M É

Le Canada est un sanctuaire pour les réfugiés depuis plusieurs générations et accueille à l'heure actuelle une nouvelle cohorte de réfugiés syriens. Les réfugiés représentent une population vulnérable au Canada, qui nécessite du soutien afin de s'établir et de prévenir la maladie mentale. Cet article décrit brièvement l'expérience du Canada avec les réfugiés et explore par la suite les défis qu'affrontent les nouveaux venus syriens, s'attardant particulièrement sur les facteurs qui contribuent à la santé mentale des réfugiés. Il est évident que les réfugiés font face à d'incroyables difficultés tout au long de leur parcours, mais que les divers systèmes de soutien au Canada renforcent considérablement leur résilience contre les troubles de santé mentale.

\section{A HISTORICAL PERSPECTIVE}

Canada is a nation of incredible diversity with inhabitants who come from all over the globe. Even before the country's establishment in 1867 the people of this land were diverse, and that diversity has grown ever since. Canada has a rich history of refugee immigration with waves of Jewish, Ukrainian, Chilean, Bengali, Vietnamese, Cambodian, and Bhutanese refugees arriving on its shores in the 1900s [1]. The recent Syrian crisis has received much attention in Canada and with a change in political ideologies in November 2015, Canada has accepted 25,000 Syrian refugees [2].

Syrian refugees, like all refugee populations, come from unique backgrounds resulting in unique needs for successful integration into Canadian society. The Canadian health care system and regional refugee agencies are experienced with receiving refugees from nations around the world and helping with their transition $[3,4]$. At a national level, the Interim Federal Health Program (IFHP) was developed to cover all incoming refugees for basic medical care and prescription drugs [4]. This essential program also covers an immigration medical exam, emergency dental services, emergency vision care as well as a pair of corrective lenses [4]. After one year, refugees in Canada can be adopted into their provincial health system [4]. Due to Canada's involvement with refugee importation, Canadian physicians are encouraged to register as Medavie Blue Cross providers in order to serve IFHP beneficiaries [5]. All of these measures are in place in an attempt to adequately support the vulnerable refugees. However, despite numerous programs and experience, issues remain with refugee integration in Canada. According to the Government of Canada "Refugees [...] often do not have the resources to easily establish themselves" [6]. Unfortunately, if not well supported, stressors for this vulnerable population can result in unique and complex mental health issues $[7,8]$. Consequently, as has been the case for all of Canada's history, the refugee integration process continues to require national investment to ensure that refugees are adequately supported.

\section{THE ROLE OF MENTAL ILLNESS}

There are key factors along the refugee journey that have been shown to predict the development of mental illness such as posttraumatic stress disorder (PTSD), anxiety, psychotic illness or depression later in life [7-10]. This can be understood in a sequential order beginning with a refugee's experiences in their home nation. The level of trauma endured through exposure to war, torture, food shortage, or abuse are known factors in predicting future mental health complications [9]. What refugees have witnessed may have a lasting impact on their ability to cope with change upon being adopted into Canada. As refugees come to Canada they may escape a food-deprived and war-torn region but they enter a part of the world completely new to them with its own set of challenges.

Refugees often have a significant deterioration in self-reported 
health status after arrival to their new home [9]. This phenomenon is likely linked to the quality or difficulty of the transition to life in Canada. Novel stressors such as language, finances, housing, and social isolation develop as soon as refugees arrive in Canada [10]. Adequate resource availability, employment and social services in welcoming communities are three more key factors in this transition $[10,11]$. These potential issues necessitate why support systems need to be in place for refugees. Otherwise the novel challenges during immigration in addition to previous emotional, physical, or spiritual trauma can manifest in adverse mental health outcomes $[9,10]$. Fortunately, Canadians are attuned to these risks and with the help of community members, refugees are commonly integrated efficiently without developing mental illness [10]. Despite previous trauma and novel stressors, approximately $90 \%$ of incoming refugees will cope well and will not be afflicted with mental illness [8]. Therefore, despite the incredible challenges faced by refugees, the support of Canadians can dramatically impact their success in a new safe home.

\section{A LOCAL PERSPECTIVE}

The refugee immigration experience is heavily dependent on the type of support they receive and the resources of their adoptive community. While all Canadian communities are unique, those accepting refugees often have similar resources that can help in the transition process. One such community is Victoria, British Columbia which has recently become home to over 200 government sponsored Syrian refugees $[12,13]$. Victoria is a representative community of many others in Canada because it has experience accepting refugees and has an agency prepared for vulnerable newcomers. The Victoria Immigrant and Refugee Centre Society (VIRCS) plays a key role in introducing refugees to their new community [3]. Societies and agencies such as this exist throughout Canada for supporting refugees and facilitating their transition [14-16]. By exploring these invaluable resources, it becomes apparent how vulnerable refugees can have successful beginnings in communities throughout Canada.

VIRCS is populated by employees who can understand the refugee experience as many of them are former immigrants or refugees themselves [13]. Many refugees initially feel as if they have lost their identity and they are invisible in Canada [13]. However, with the support of VIRCS employees and volunteers, refugees can begin to integrate into their new world. Within months refugees gain employment, get their driver's licenses, buy houses and learn to speak English [13]. This form of healthy integration is the goal of VIRCS and is what drives each member of the organization [3].

VIRCS and similar societies in Vancouver, Toronto and Ottawa offer many programs to incoming refugees in order to ease the integration process [14-16]. Health, finance, shopping, yoga, and language workshops are highly sought after and are offered for free to the refugees [13]. With large waves of refugees, VIRCS also hosts a skills connect event where refugees are connected to employers in their previous profession. These resources are tuned specifically to the needs of refugees and are offered because of their effectiveness in achieving the goals of VIRCS.

Agencies such as VIRCS possess Canada's experts for working with refugees and they can anticipate many of the potential issues for new cohorts of refugees $[3,13]$. At VIRCS they realize that refugees in a new country have lost their friends, family, profession, culture, and food. They know that their clients have also experienced war, lost loved ones and have been forced to abandon everything they know [13]. Consequently, VIRCS identifies mental health as the number one health issue for their clients and has taken steps to address the potential need for counselling [13]. An Immigrant and Refugee Wellness Centre for Syrian refugees was recently established in Victoria with the support of VIRCS [13]. This new centre, supported by trained volunteers, is designated for providing comprehensive trauma counselling for refugees [13]. Other health issues such as tuberculosis or malnutrition can be managed in Canada, but mental health issues are the most concerning to VIRCS as they are the most complicated [13].

The cohort of Syrian refugees settling in Victoria is $75 \%$ children who face unique challenges but have the most potential as future Canadians [13]. Refugee children often initially miss their friends and former culture, but with the efforts of individuals at VIRCS and other refugee agencies throughout Canada, children adapt and integrate easily. In some cases, counselling may be necessary for helping children cope with previous trauma and to prevent possible issues with anger and violence [13]. Given support, within ten years refugee children will learn a new language, make friends, grow up, go to university and eventually pay back into the economy which brought them here [13]. Victoria, like many other Canadian communities, has incredible resources for refugees which can help with their challenging transition.

\section{CONCLUDING REMARKS}

Canada has been accepting refugees for over 100 years and has developed systems to properly support and integrate this vulnerable population. Refugees have access, both nationally and regionally, to resources that can help them cope with previous trauma and explore options for their future in Canada. Agencies and programs such as VIRCS and the IFHP allow refugees to gain new employment, learn English, and access counselling; all key factors in a refugee's integration. However, with all of these services there will continue to be unique challenges for incoming waves of refugees. Amid the current Syrian importation, housing shortages have evolved in many major Canadian cities, which has likely inflicted stress on the newcomers [17-19]. Yet despite 


\section{Commentary}

this additional stressor, the data suggest that the resilience of the refugees will help them overcome this challenge [7]. All of the resources available to refugees in Canada bolster their resiliency, thus resulting in controlled levels of mental illness in populations who have survived incredible trauma. The level of support provided to refugees is a major predictor of future well-being and Canadians must remain committed to ensuring that our nation is equipped to welcome global citizens in need.

\section{REFERENCES}

1. Government of Canada [Internet]. Immigration: Canada: A history of refuge; [updated Jun 2012, cited 2016 Mar 9]. Available from: http://www.cic. gc.ca/english/games/teachers-corner/refugee/refuge.asp.

2. 25,000th Syrian refugee lands in Canada [Internet]. CBC News; 2016 Feb 27 [Cited 2016 May 29]. Available from: http://www.cbc.ca/news/canada/ montreal/25-000th-syrian-refugee-lands-in-canada-1.3467886.

3. Welcome to VIRCS: Our mission [Internet]. Victoria Immigrant and Refugee Society; [cited 2016 Mar 28]. Available from: http://www.vircs.bc.ca/content/about.

4. Government of Canada [Internet]. Determine your eligibility - Interim Federal Health Program; [updated May 2016, cited 2016 Mar 11]. Available from: http://www.cic.gc.ca/english/refugees/outside/arriving-healthcare/ individuals/apply-who.asp.

5. Information Handbook for Health-care professionals. Immigration, Refugee and Citizenship Canada, Medavie Bluecross; [updated April 2016, cited 2016 April 8]. Available from: http://www.cic.gc.ca/english/refugees/outside/arriving-healthcare/practitioners.asp.

6. Government of Canada [Internet]. Immigration: The refugee system in Canada; [updated Nov 2015, cited 2016 Mar 11]. Available from: http://www. cic.gc.ca/english/refugees/canada.asp.

7. Kirmayer LJ, Narasiah L, Munoz M, et al. Common mental health problems in immigrants and refugees: general approach in primary care. Canadian Medical Association Journal. 2011;183(12): 959-67.

8. Fazel M, Wheeler J, Danesh J. Prevalence of serious mental disorder in 7000 refugees resettled in western countries: a systematic review. The Lancet. 2005;365(9467):1309-14.

9. Pottie K, Greenaway C, Feightner J, et al. Evidence-based clinical guidelines for immigrants and refugees. Canadian Medical Association Journal. 2011;183(12): 824-925.

10. Kirmayer LJ, Narasiah L, Munoz M, et al. Common mental health problems in immigrants and refugees: general approach in primary care. Canadian Medical Association Journal. 2011;183(12):E959-67.

11. Carlsson JM, Olsen DR, Mortensen EL, et al. Mental health and health-related quality of life: a 10-year follow-up of tortured refugees. The Journal of nervous and mental disease. 2006;194(10):725-31.

12. Victoria to receive up to 400 refugees this year [Internet]. Times Colonist; 2016 Feb 5 [Cited 2016 May 18]. Available from: http://www.timescolonist.com/news/local/victoria-to-receive-up-to-400-syrian-refugees-thisyear-1.2167029.

13. Okot Ochen, A. Victoria Immigrant and Refugee Centre Society. Personal interview; 2016 Mar 10.

14. About: Mission Statement [Internet]. Inland Refugee Society of BC; [cited 2016 Aug 28]. Available from: http://inlandrefugeesociety.ca.

15. Welcome to the Christie Refugee Welcome Centre [Internet]. Christie Refugee Welcome Centre; [cited 2016 Aug 28]. Available from: http://christiestreetrc.com.

16. About us: OCISO [Internet]. Ottawa Community Immigrant Services Organization; [cited 2016 Aug 28]. Available from: http://ociso.org.

17. Kerur S. Refugees' needs expose Canada's housing crisis [Internet]. The star; 2016 Feb 5 [2016 Apr 22]. Available from: https://www.thestar.com/opinion/commentary/2016/02/05/refugees-needs-expose-canadas-housingcrisis.html.

18. Turner C. Refugee agencies making headway in housing Syrians, but thousands still need homes [Internet]. CBC News; 2016 Mar 8 [Cited 2016 May 11]. Available from: http://www.cbc.ca/news/canada/refugees-housingmoving-in-1.3476893.
19. Thomas M. Refugee sponsors struggle to find available housing in Victoria [Internet]. CBC News; 2016 Jan 13 [Cited 2016 Apr 22]. Available from: http://www.cbc.ca/news/canada/british-columbia/refugee-sponsorsstruggle-to-find-available-housing-in-victoria-1.3401185. 